\title{
里山二次林そして自然性の高い森林におけるアメニティ
}

\section{香川隆 英*}

\author{
Studies on the Amenity of Coppice and Natural Forest
}

Takahide KAGAWA

\begin{abstract}
摘要 : 本報告の月的は，森林のアメニティの㭶造を明かにすることである。そのため，羁なる属性の人々に，羁なる

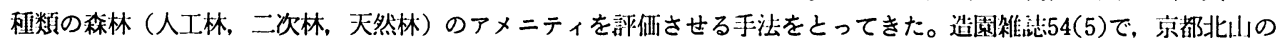
人工林のアメニティを明かにしたのに引き続き，本報告では二次林および天然林のアメニティの槛造を解きほぐした。

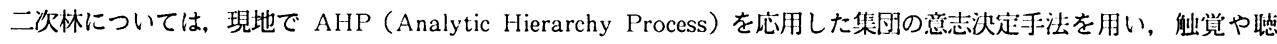
覚，豀覚に関わる林内環境因子がアメニティを規定することを示し，天然林では，アンケートを用いたAHPにより， 森の舆行きや生隹的自然度の高さがアメニティの主因子であることを示した。
\end{abstract}

\section{1.はじめに}

わが国は，エコロジカルにも人との歴史的なつながり においても，様々な種類の森林が存在し（エコロジカル には亜寒帯から亜熱帯まで, 人とのつながりではブナや クヌギの二次林から北山スギ林，明治神宮の森まで）, 気候的にも森林の成立条件に恵まれており，森林の占め る比率が高い。このような，森林のアメニティを得るた めの条件がふんだんにあるにも関わらず，現実に人々は 多様な森林のアメニティを十分に享受しているとは思わ れない。それは，現象面では特に都市周辺地域では，身 近な緑が物理的に減少しているために日常的な緑欠乏状 態にあること，また森林地域においても林業の不振のた め, 森林そのものの基本的な整備よりリゾートに付帯す る施設等の整備にばかり目がむけられていること，そし て人々の趣向面においては，森林の中に身を委权森林自 身のアメニティをゆったりと満契するより，リゾート内 の施設を駆け足でまわる傾向が強いといった現状から同 い知れる。しかしながら，森林のアメニティはもっと深 遠で，その効用を十分に得られるように森林整備をした り, 人々の生活の中に森林の楽しみかたが浸透すれば, 森林はより健全になり, 人々は今以上に森林からのアメ ニティを享受できるようになる。そして，その実現のた めには, まず基本的な森林のアメニティの構造が明かに されなければならない。

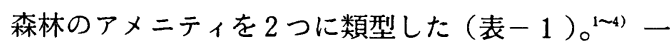
つは, 森林自身, そのものの持つアメニティであり, 本 研究の対象としているところである。それは, 天然林, 二次林，人工林之様々な森林はあろうが，それらの森林
にじかに触れることで得られるアメニティである。二つ めは，森林にスキー場など施設を設置し，主に施設利用 が目的で, 森林の存在が付随的になる場合である。この

\section{表ー 1 森林のアメニティ}

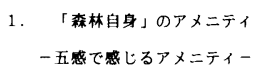

図ー1＼cjkstart森林のアメニティを評価する主体と客体

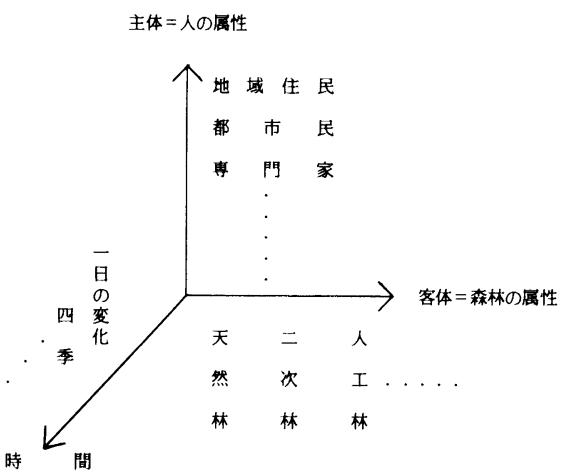

•農林水産省森林総合研究所 


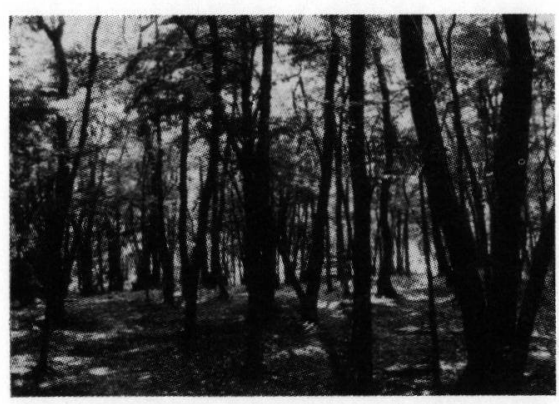

写真ー 1 クヌギ・コナラ林

場合, アメニティのよりどころは, 施設の内容にかなり 依存する。森林自身のアメニティは，五感を快適にする 因子で成り立っているが, 皆が平均的に快適と感じる因 子もあれば，人々の育った環境や感性の違いなどで因子 の快適さが逆転する場合むあり得る。これは，評価する 主体である人の属性の問題である。人の属性む評価され る森林の属性も時間軸によって影響を受け, それら 3 者 の関係を解きほぐしていくことがアメニティ解明の糸口 を与える (図一 1 )。

本研究は大きく 2 つに分かれる。まず, 里山二次林の アメニティの構造, 構成因子およびそれぞれの因子の重 要度を明かにするために, 里山二次林に親しい造園の学 生を選び, 現地においてAHP (Analytic Hierarchy Process）を応用した集団の意志決定手法により解析を 試みた。次ぎに, 天然林のアメニティの構造, 構成因子 およびそれぞれの因子の重要度を明かにするために，利 用者の代表である都市居住者に, アンケートを用いた AHPにより解析を行った。

\section{2. 里山二次林のアメニティの調查結果}

クヌギ, コナラ林に代表される里山二次林は, 日本人 の最む好む景観の一つに数えられている。的ただし，適 度な人為的コントロールが加えられていることが前提と なるが。人手が加えられなくなった林内空間は，低木や 下草が生い茂り，アクティビティに適さなくなる。

\section{(1) 調查の方法}

調査は, 1990年 8 月 9 日, 調查箇所は埼玉県北本市の 平地林で行った。アメニティの評価者は, 千葉大学の造 園学科の学生 5 人であり, 彼らの属性の特徴は, 現在都 市近郊に居住する森林のアメニティに比較的関心の高い 若い世代と言える。調查箇所は, 宅地開発で虫食い状態 にされている状況のなかで，何とか残存しているコナラ 主体の平地林で, 灌木, つる類, 高茎草本など刈り払わ れており，管理状態は良く林内は歩きやすい (写真 -1 )。 調查時の環境は, 夏の晨空からときおり晴れ間がのぞく 蒸し暑い天候であった。調查の手順は, 学生 5 人に評価 対象森林をしばらく体験させ，現地においてAHPを応 用した集団の合意形成による意思決定により,アメニティ
因子の抽出, アメニティ因子の階層化，一対比較による 各因子の重み付けを行った。また，現地でパソコンを用 いて整合性のチェックを行った。アメニティの階層構造 及びそれぞれの因子のウエイトを図ー 2 に示す。6)

(2) 結果之考察

\section{「二次林のアメニティ因子」}

因子の階層構造の特徵は, 人工林のアメニティが外か ら森林を見る景観の因子を主体に構成されていたのに対 し, ${ }^{7)}$ 二次林では, 林内環境や林内での行動性など日常 的に森林内を利用することに重きがおかれている（表一 $2)^{8)}$ つまり, 人工林のアメニティとは人々にとって 外から眺める対象, 一定の距離をおくむのであるが，二 次林のそれは, 人々が直接森林に触れ，林内に入り利用 することで得られるものなのである。因子は，最初の階 層で大きく 4 分され，そのウエイトは林内環境（ $\mathrm{W}$ : 0.50) が最も大きく, 林内の行動性（w：0.29）, 自然 性 ( $\mathrm{w}: 0.14)$, 景観 ( $\mathrm{w}: 0.07)$ と続いた。林内の快 適な環境が最も重視されたのは，住宅地に隣接する二次 林のアメニティの特徽を良く表している。身近な都市内 のオアシス，㮩いの場として期待されるところが大きい。

階層 3 までで, 自然性, 行動性, 林内環境は構成因子 がほぼ出尽くしたが, 景観は階層 6 まで深められた。これ は, 評価者が造園の学生で景観に対する認識が高いこと と，景観には林外からの評価も加わるためと考えられる。

表ー2 クヌギ・コナラニ次林のアメニティ因子評価

\begin{tabular}{|c|c|c|c|c|c|}
\hline & 林 内 & 行 助 & 自 然 & 貫 & ウエイト \\
\hline 林内摆境 & 1 & 3 & 3 & 5 & 0.50 \\
\hline 行 性 & & 1 & 3 & 5 & 0. 29 \\
\hline 然 性 & & & 1 & 3 & 0.14 \\
\hline 锁 & & & & 1 & 0.07 \\
\hline
\end{tabular}

表一 3 林外景観のアメニティ因子評価

\begin{tabular}{|c|c|c|c|c|c|}
\hline & 森 の大きさ & 色 & 多拣性 & 森のまとまり & ウェ 1 ト \\
\hline 森の大きさ & 1 & 3 & 3 & 5 & o. 52 \\
\hline 彩 & & 1 & 3 & 3 & 0.26 \\
\hline 多粎 性 & & & 1 & 1 & 0. 12 \\
\hline 秝のまとまり & & & 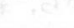 & 1 & 0.10 \\
\hline
\end{tabular}

表 -4 林内中層景観のアメニティ因子評価

\begin{tabular}{|c|c|c|c|c|c|c|c|}
\hline & & 密 度 & 下枝 & 形 & 太 & 木のはた & ウx1ト \\
\hline 密 & 度 & 1 & 3 & 5 & 5 & 7 & 0.49 \\
\hline 下 & 技 & & 1 & 3 & 5 & 7 & 0.28 \\
\hline 㣮 & 形 & & & 1 & 3 & 3 & 0.12 \\
\hline 太 & さ & & & & 1 & 1 & 0.06 \\
\hline 木 の & 肌 & & & & & 1 & o. 05 \\
\hline
\end{tabular}

表-5 林内中層景観の木の肌のアメニティ因子評価

\begin{tabular}{|c|c|c|c|c|c|}
\hline & コナラ & ク キキ & アカマッ & シ テ & ウエトト \\
\hline コナラ & 1 & 3 & 5 & 7 & 0.55 \\
\hline クヌキ & & 1 & 3 & 5 & 0.26 \\
\hline アカマッ & & & 1 & 5 & 0.14 \\
\hline シ テ & & \multicolumn{5}{c|}{ C. R. (整合比) $=0.089$} \\
\hline
\end{tabular}




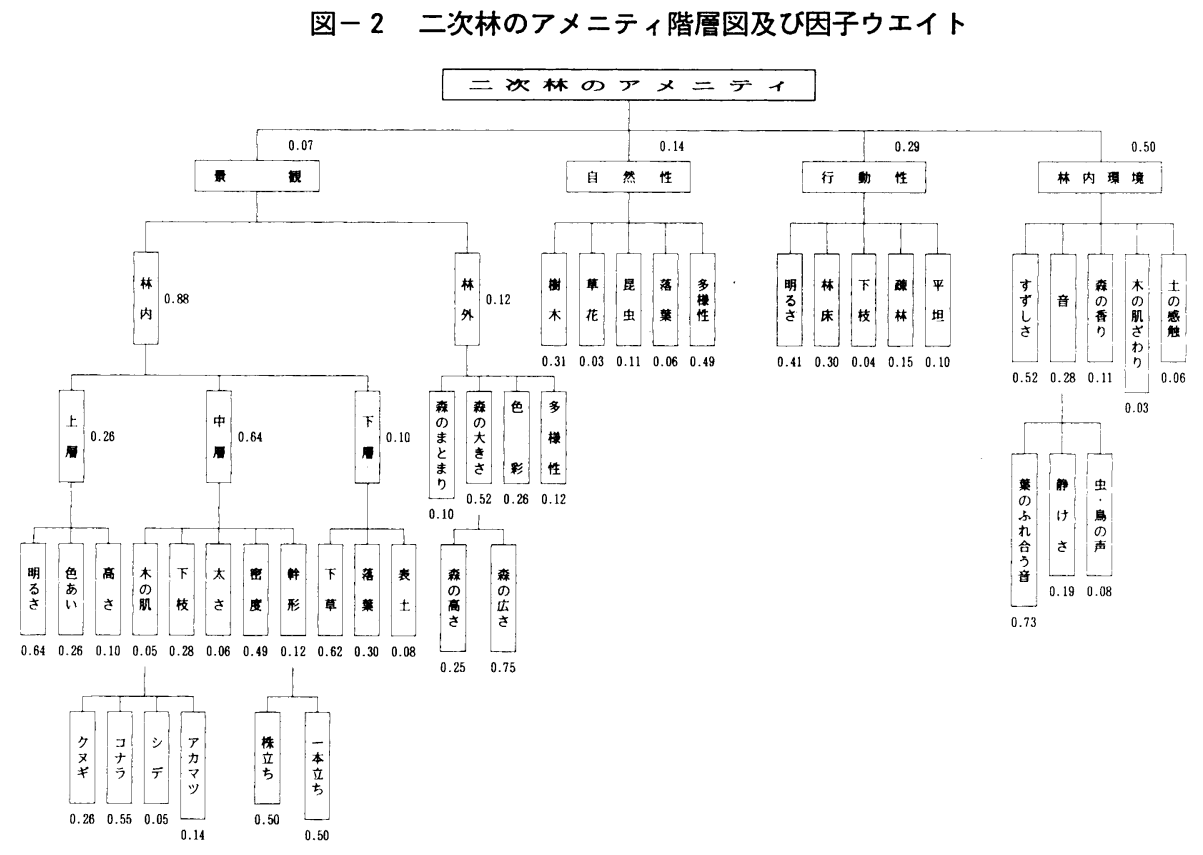

パソコンを用いた整合性のチェックは，因子の数が少 ない（4 個程度）と有効だが（2 度目の評価で整合性が 高まる)，多いとそれほど寄与しない傾向が見られた。

「景観」

景観はそれ自信のウエイトは必ずしも高くないが，構 成する因子は最も複雑で深い階層を呈した。まず林内 （w：0.88）と林外 ( $\mathrm{w}: 0.12)$ に 2 分された。ウエイ 卜は林内が高い。日常的に直接林内で体験することに重 みがおかれている。その下の階層では，林内は更に上層 $(\mathrm{w}: 0.26)$, 中層 $(\mathrm{w}: 0.64)$, 下層 $(\mathrm{w}: 0.10)$ に分 けられ，目線の位置としての中層のウェイトが高い。林 外では, 緑量としての森の大きさ $(\mathrm{w}: 0.52)$ に色彩 （w：0.26）が続く（表一-3）。森の大きさには，広さ （w：0.75）の方が高さ（w：0.25）より効いている。 林内の上層は，木漏れ日の明るさ ( $\mathrm{w}: 0.64)$ が最も効 き, 落葉広葉樹の柔らかい色合い（w：0.26）が続く。 中層は，見通しのよい開放的な景観を創り出す適度な密 度（w：0.49）とそれを補完する下枝の少なさ（w： 0.28）が重要な因子となる。通直なあるいは穏やかなカー ブを描く幹の形（ $\mathrm{w}: 0.12)$ が評価され, 幹の太さ（w： 0.06) と木の肌 ( $\mathrm{w}: 0.05)$ が続く（表一 4 ）。幹の形 は, 一本立ち ( $\mathrm{w}: 0.50)$ と薪炭林及びほだ木生産林に 特有の株立ち（w：0.50）が同定度に評価された。木の 肌は樹種まで因子が細分化された（表一 5 ）。コナラ （w：0.55）は, 白と黒の縞模様にコルク層の厚みが立 体感を演出し, 最も好まれた。クヌギ（w：0.26）がそ れに続いたが,コナラに比べると色彩のメリハリに少し かける。アカマッ（w：0.14）は, 京都の東山のそれに
比べると若いのでさほど高い評価は得られない。クマシ デ（w：0.05）は数の少ないこともあって存在感に乏し いし，木肌の立体感はない。下層は，表土（w：0.08） が露出するより草本 $(\mathrm{w}: 0.62)$ や落葉 $(\mathrm{w}: 0.30)$ に 被われる景観が好まれる。

「自然性」

自然性を構成する因子は, 多様性（w：0.49）のウエ イトが最も高い。野生生物や樹木, 草花といった生態系 の多様性, 四季や日中の光の变化による彩りの多様性な ぞ肌理の細かい微妙な変化が自然性を代表する。次いで 樹木（w：0.31）の評価が高い。特に珍しい野生生物な ぞの少ない二次林の特徵と考えられる。昆虫 ( $\mathrm{w}: 0.11)$, 落葉 $(w: 0.06)$, 草花 $(w: 0.03)$ と続く。

\section{「行動性」}

行動性を構成する要因は, 明るさ（w：0.41）と林床 （w：0.30）が大きい。明るさは安心感, 安全性にもつ ながるだろうし, 林床の低木や草本層の密度や高さが直 接歩きやすさに関係する。樹林の密度 ( $\mathrm{w}: 0.15)$ や地 形的要因 $(w: 0.10)$, 下枝の整理 $(w: 0.04)$ がこれ らに続き，行動性に影響を及ぼす。

\section{「林内環境」}

林内環境を構成する因子ウエイトは，涼しさ（w： 0.52）が最も大きい。これは, 調查時期が夏である事に 関連しょう。次いで林内の音 $(\mathrm{w}: 0.28)$ のウエイトが高 く，その構成因子で静けさ $(w: 0.19)$ よりも葉のふれあ う音( $\mathrm{w}: 0.73) に$ 高いアメニティを与えるのは, 造園の 学生らしい感性の高さを示す。森の香り ( w : 0.11), 土の感触 $(w: 0.06)$, 木の肌ざわり $(w: 0.03)$ が続く。 


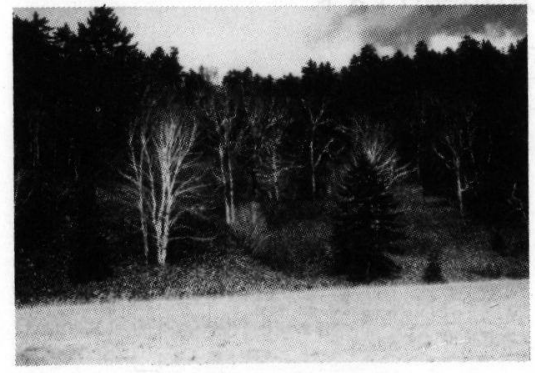

写真一 2 天然林

\section{3. 天然林のアメニティの調查結果}

一口に天然林之言っても, 南は屋久スギの原生林から 北はアカエゾマツ林まで多様である。しかしながら，一 般の人々にとっては, 屋久スギの様な特別な森林を除け ば,アカエゾマツ林あトドマツ林もモミ，ッガ林む大き く差異は感じないものと思われる。ただし, ブナ林（落 葉広葉樹林）とトウヒ林（常緑針葉樹林）では異なって こよう。本研究では, ウラジロモミやオオシラビソなど の亜高山性針葉樹にダケカンバなどの落葉広葉樹が混交 する, 尾瀬周辺の森林を天然林として代表させた（写真 2 )。

\section{(1) 調査の方法}

評価者の属性は, 首都圏近郊の家族連れグループで, 小学生とその両親180名である。このグループは, 東武 コミュニティー文化センターが企画した, 第 5 回会津高 原親子自然教室の参加者である。期間は, 1990年 8 月 8
日〜12日まで, 内容は, 尾瀬周辺の散策, ナイトハイク や木工教室, 野外料理, スターウオッチングなどの自然 体験, 学習や, ニジマスつかみ, 野外スポーツ大会, キャ ンプファイヤー, コンサートなどの各種イベントである。 楽しかったイベントのアンケート結果は, 子供達は, 二 ジマスつかみどり, 自然の中でのスポーツ大会, ジャガ イモ掘りといった自然に直接触れるアクティブでスリリ ングなイベントを選んだのに対し, 両親は, サロンコン サート, 親子コンサート, オプショナル（尾瀬周辺の散 策）といった自然環境の中での芸術体験や自然観賞など 静的なイベントを選んだ（表一6）。親の世代は，日常 忙しく雑事に追われている喧噪の生活から，一服の安ら ぎ，一時の贅沢さを味わい，子供達は不慣れなはずの自 然とじかに接し，遊ぶことに何のためらいもなく溶け込 んだ。適応力の早さは評価できるが, 野生生物との出会 いを大切にした, 自然の中での遊びの必要性が再認識さ れる。このアンケートとは別に, 森林のアメニティに関 わるアンケートをかけた。アンケートにより，AHPを 応用した手法でアメニティを評価するために，天然林の アメニティの階層構造, 構成因子は文献等を参考に事前 に定めておいた。 ${ }^{9)}$ 構成因子の数は, 一対比較が繁雑に なりすぎないように，同一階層内 3 個とした。因子ウエ イトは, 70 人の大人の評価の平均值である (図-3)。

(2) 結果と考察 「天然林のアメニティ因子」

因子ウェイトは, 森の深さ（w：0.46）の評価が高い

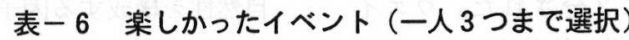

\begin{tabular}{|c|c|}
\hline 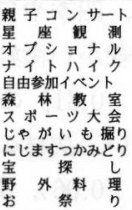 & $\begin{aligned} 15 & \text { 名 } \\
- & \\
15 & \text { 名 } \\
18 & \text { 名 } \\
15 & \text { 名 } \\
0 & \text { 多 } \\
34 & \text { 名 } \\
30 & \text { 名 } \\
37 & \text { 名 } \\
15 & \text { 名 } \\
12 & \text { 多 } \\
28 & \text { 名 }\end{aligned}$ \\
\hline
\end{tabular}

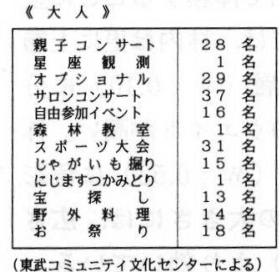

図ー3 天然林のアメニティ階層図及ひ因子ウェイト

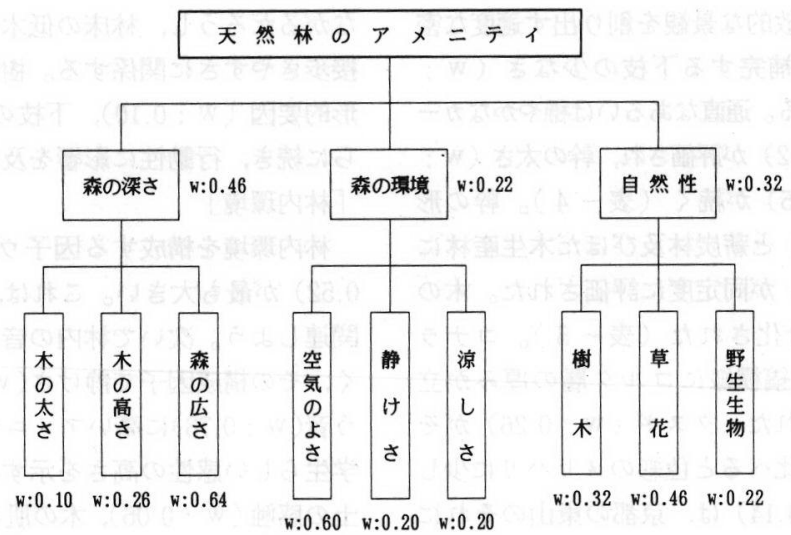


（表一 7 ）。天然林の神秘性など非日常的魅力が要因で あると考えられる。北山の磨き丸太林では人工的整形美 が，クヌギ、コナラ二次林では都市ストレスを癒すため の身近な林内環境がアメニティの主題となった事実と対 照的である。二次林には日常のアメ二ティを, 天然林に は非日常のアメニティが求められている。自然性（w : $0.32)$ が森の深さに続き, 森の環境 ( $\mathrm{w}: 0.22)$ よりも 評価が高い。

\section{「森の深さ」}

森の深さを構成する因子のウエイトは，森の広さ（w： 0.64), 木の高さ ( $\mathrm{w}: 0.26)$, 木の太さ $(\mathrm{w}: 0.10)$ と 続く（表－8）。二次林の森の大きさを構成する因子で, 森の高さ（w：0.25）より森の広さ（w：0.75）のウエ イトが高かったことと共通する。しかしながら，京都の 一般用材人工林の壮大さの評価では, 専門家集団は, 直 径 ( $\mathrm{w}: 0.39)$, 樹高 $(\mathrm{w}: 0.39)$, 森の広さ ( $\mathrm{w}: 0.15)$ の順に高いウエイトをおいている。森林の深さ，大きさ とそれを構成する因子間の評価は, 評価基準が比較的物 理的なので森林の種類より, 評価する人の属性によると ころが大きい。専門家が直径や樹高を壮大さの第一要因 とするのは，いくら広い森林であってもまだ若い，生育 途上の森林に壮大さを感じないからである。専門家が森 の質にこだわっている姿勢が同える。

「自然性」

自然性を構成する因子のウエイトは, 草花 (w：0.46), 樹木（w：0.32）, 野生生物（ $\mathrm{w}: 0.22 ）$ の順である (表- 9 )。草花の評価が高いのは, 尾瀬の湿原植生が効 いている。野生生物の豊富さは, 短期間の林内散策では, 特に大型の野生生物に出会えることが少ないので評価は 低くなる。

\section{「森の環境」}

森の環境を構成する因子のウエイトは，空気のよさ （w：0.60）が最も高く, 静けさ, 涼しさ（w：それぞ れ0.20）が続く（表-10）。空気のよさが最も効いてい るのは，当地域が強い森の香りを有する亜高山針葉樹林 で, しかも評価者が自然の森の香りに触れることの少な い都市居住者であることに起因する。また，京都北山の 一般用材人工林の林内環境で, 北山森林組合の人々は静 けさと涼しさに同定度のウエイトを与え, クヌギ,コナ ラ二次林では造園の学生が涼しさを静けさより高く評価 している。しかしながら, 二次林の調査時の環境が, 涼 しさに高い評価が集まる時期であったことを考えると， 評価者が異なるので厳密にはいえないが，林内環境の涼 しさと静けさという 2 つ因子は，同定度のウエイトを 有するものと考察できる。

\section{「アメニティの嗜好」}

このアンケートの中で, 自然性の高い森林と明るい森 林公園で代表されるような森林, 公園の芝生広場を步く
表ー7 天然林のアメニティ因子評価

\begin{tabular}{|c|c|c|c|c|}
\hline & 深さ & 理境 & 自然 性 & ウェイト \\
\hline 森の深さ & 1 & 3 & 1 & 0.46 \\
\hline 森の垷境 & & 1 & 1 & 0.22 \\
\hline 自 然 性 & & & 1 & 0.32 \\
\hline
\end{tabular}

表ー8 森の深さのアメニティ因子評価

\begin{tabular}{|c|c|c|c|c|}
\hline & 木の高さ & 木の太さ & 森の広さ & ウエイト \\
\hline 木 の高さ & 1 & 3 & $3 / 1$ & 0.26 \\
\hline 木の太さ & & 1 & $5 / 1$ & 0.10 \\
\hline 森 の㕕さ & & & 1 & 0.64 \\
\hline
\end{tabular}

表一 9 自然性のアメニティ因子評価

\begin{tabular}{|c|c|c|c|c|}
\hline & 时木 & 野草 & 野生生物 & ウエイト \\
\hline 㴻木の曹富さ & 1 & 1 & 1 & o. 32 \\
\hline 野草の害富さ & & & 3 & 0. 46 \\
\hline 野 生 生 & & & 1 & 0.22 \\
\hline
\end{tabular}

表ー10 森の環境のアメニティ因子評価

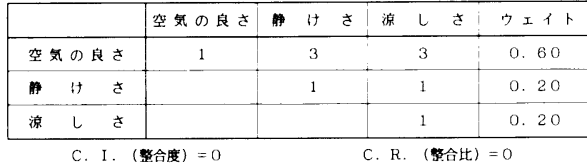

場合の快啇性について問うたところ，81\%の人が整備さ れた森林公園よりも自然性の高い森林の中を歩きたいと 考え, $77 \%$ の人が，芝生広場より整備された森林公園を 歩きたいとしている。この結果は, 北村らが行った各国 別の人々の森林に対する親しみ度の違い(10)や, 鈴木, 掘 が行った森林の夕イプ別親し 及度の評価結果 ${ }^{(5)}$ 之, 表面 的には異なっているように見える。北村らの調査結果で は, ヨーロッパの人々に較べ, 日本人は深い森の中へは いることを嫌う人が多いとし, 掘らは, 人々は深い森よ り人手の加わった二次的な森を好むとしている。しかし ながら，この自然教室で人々が体験したような，優れた インストラクターによる案内のもと, 質の高い自然の中 でじっくりと様々な自然体験を経験することによって, 人々の深い森に対する理解が樑まり, 親近感が増し, ア メニティが高まるのである。このことは, 総理府の行っ た，森林に関するアンケートでも裏づけられる。 天然 林と人工林の違いを知っていると答えた者 $(1,273$ 人) に, 森林の 6 割が天然林で 4 割が人工林である現状をど う考えるかという質問に，天然林を増やすべきだと答え

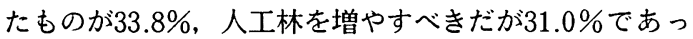
た。しかしながら，この内 1 年間に森に入ったことのあ る者は $37.9 \%$ が天然林を増やすべきだとし，森に入った ことのない者の $24.0 \%$ 大きく上回っている。つまり， 森林に対する見かけの親しみの薄さは，自然性の高い森 林の理解か深まり, 天然林との楽しいつき合い方を習得 することで，本質的な親しみの深さ，高いアメニティの 享受へと変化していくのである。 


\section{4. まとめ}

里山二次林のアメニティと天然林のアメニティを, 前 者はクヌギ, コナラ林において, 都市に住む森林のアメ ニティに関心をもつ集団の意志決定により, 後者は天然 林の中で過ごした都市近郊在住者にアンケートを用いて, それぞれAHPを応用した手法で明らかにした。

里山二次林の現地における評価では, 集団の意志を取 りまとめるために被験者を 5 人としたが, 因子の階層が 深められた反面, 評価の汎用性に問題が残った。天然林 のアンケートを用いた評価では，因子の構成が単純となっ た。また，それぞれの森林の評価者の属性が異なるので, 単純比較はできない。時間軸を評価尺度に加えることと あわせて, 今後の課題としたい。二次林のアメニティで は, 五感でいえば触覚や聴覚, 嗅覚に関与する林内環境 因子に高いウエイトが与えられた。また, ウエイトは低 かったが，景観は最も構成因子が複雑で深い階層を呈し た。しかも, 他の因子に較へ唯一林外からの評価が加かっ た。

天然林のアメニティでは, 視覚が主に関与する森の奥 行き, 神秘性の因子に高いウエイトが与えられた。それ ぞれの森林におけるアメニティを構成する因子を概括す ると, 二次林のアメニティが, 日頃の都市生活ストレス を身近な林内環境で癒す日常のアメニティで代表させら れるのに対し, 天然林のそれは, 刺激的な非日常の体験 から得られるアメニティといえよう。これらに対し，人 工林のアメニティは, 比較的日常の, ただし少し距離を おいた外から眺めるアメニティの範疇に入れられよう。 このように, 森林の質が異なれば, そこから得られる, 言い替えればその種の森林に要求されてくるアメニティ の質も異なってくる。それらアメニティが最も高度に得 られるような森林の取り扱いが, 今後ますます必要となっ てこよう。なお, 里山二次林の調査にあたっては, 森林 総研の田中伸彦君及び千葉大学の学生諸君に, そして天 然林のアンケートには, 東武コミュニティー文化センター の紫桃満之, 川部利一氏, 山口営林署長の上野司郎氏及
び自然教室に参加されアンケートにご協力頂いた皆さん に感謝致します。

\section{補注およひ参考文献}

1) $\mathrm{AMR}$ (アメニティミーティングルーム) 編 : アメ ニティを考える : 未来社, 1989

2 ) 小林享 : 気象景観体験における感覚印象操作の可能 性に関する考察 : 造園雑誌 53(5), 199-204, 1990

3 ) 武内和彦, 横張 真, 井手 任: 田園アメニティ論, 43-74, 養賢堂, 1990

4 ）柳哲雄 : 風景の構造 : 創風社出版, 1990

5 ）鈴木修二, 掘 繁 : 森林風景における自然性評価之 好ましさに関する研究 : 造園雑誌 $52(5), 211-216$, 1989

6 ）刀根薫, 真鍋龍太郎 : 階層化意志決定法AHP事例 集 : 日科技連, 1990

7 ）香川隆英 : 京都北山における人工林のアメニティに 関する研究: 造園雑誌 54(5)，185-190，1991

8 ）表は, 比率尺度の一対比較を表し，1 ; 同程度, 3 ; やや重要, 5 ; 重要, 7 ; かなり重要とした。また, C.I. (consistency index) ; 整合度は C.I. = $\lambda \max -\mathrm{n} / \mathrm{n}-1$ で表され，この $\mathrm{n}$ 個の固有值をも つ行列 Aが完全な整合性をもつ場合は C.I. は 0 で あり，值が大きくなれば整合性は低くなる。一方,

C.R.(consistency ratio); 整合比は, C.R.=C.I. /M（Mは，一対比較值をランダムに入れた行列 A の C.I. を多数回計算した平均值）で表される。 C.I. が0.1以下で，C.R.が0.15以下であれば整合性 が高いとされている。

9 ) 香川隆英 : 森林の保健休養機能に関する一考察 (1) : 101回日林論, 153-156, 1990

10）北村昌美 : 森林環境に対する国民意識の研究 : 昭和 59, 60年度科学研究費補助金研究成果報告書, 1986

11）内閣総理大臣官房広報室 : 森林と生活に関する世論 調查 : 総理府, 1990

Summary: This study intends to make clear the amenity of coppice and natural forest. The amenity of coppice has been estimated by using an applied method of AHP (Analytic Hiera rchy Process). This is one of the method of decision making in group. And the amenity of natural forest has been estimated by using a questionnaire applicating AHP.

The results of two methods indicate that the most important factor in coppice is environm ent in forest. This is concerned with the sense of smell and tactual, hearing sense. And in natural forest the most important factor is deepness of forest. 